\title{
Development of an Instrument to Evaluate the Effectiveness of a Subject in a Study Programme- ELTA Model
}

\author{
T. Sathaananthan ${ }^{1}$, S. Sathaananthan ${ }^{2}$ \\ ${ }^{1}$ Department of Medical Education and Research, Eastern University, Sri Lanka \\ ${ }^{2}$ Department Mathematics, Faculty of Science, Eastern University, Sri Lanka
}

\begin{abstract}
Measure the effectiveness of a subject in a study programme is very essential activity at all levels of the education system, from primary through post-secondary education. Educational concepts, Learning environment and resource management, Teachinglearning process, and Assessment (ELTA) were identifiedas important parameters to the effectiveness of a subject. As such this paper developed amodel named as ELTA to measure the effectiveness of a subject in a study programme. The development of the model is based on the factthat the effectiveness of learning process is influenced by the level of satisfaction of the stakeholdersand also results from the total synergy used in the learning process. The model was validated through interviews with stakeholders. The validation revealed that the model offers valid, reliable, and useful results for evaluating the effectiveness of a subject that claims to be generic to subject and non-culturally specific.
\end{abstract}

Keywords: Effectiveness, satisfaction level, learning process, component analysis, ELTA Model

\section{Introduction}

Students in a fast-moving, technological-oriented society demand efficiency in terms of learning effectiveness and time. Of course, the effectiveness of a course depends upon many factors, as well as the actual amount of learning itself. How- ever, effectiveness is an elusive concept and measuring effectiveness is not simple. There is a general agreement in the literature that teaching effectiveness is multi-perspective in nature. Many studies have identified factors that influence teaching effectiveness for face-to-face mode, including the course organization, instructor's enthusiasm, breadth of coverage, class size, the type of course, student abilities, and grading policies (Abrami, D’Apollonia, \&Rosenfield, 1997; Centra, 1994; Cohen, 1981, 1987; Feldman, 1989; Marsh \& Dunkin, 1997; Young \& Shaw, 1999). Some of these factors can be applied for measuring the effectiveness of an online delivery system. However, the importance of social environmental factors such as social interfacing, communication, interaction, engagement, participation, or other inspirational factors should not be overlooked. Studies show that social presence affects outcomes as well as the student satisfaction (Richardson \& Swan, 2003). The principle of the constructivist theory of learning indicates that a student's entire psychological, physiological, and emotional energy is engaged in the learning process and that process is impacted by the environment.

Though the definition for effectiveness is varying in different literature in general, it shows to what extent the expected accomplishments are achieved or how well the outcomes meet the stated goals(Yilmaz \& Tasdan 2006; Rupsiene \& Bartuseviciene 2008). The effectiveness of a course depends upon many factors, as well as the actual amount of learning itself. However, the effectiveness is a broader concept and it is difficult to define and measuring effectiveness is not a simple task. There is a general agreement in the literature that effectiveness of teachinglearning process is multi-perspective in nature. Many studies have identified factors that influence the effectiveness teaching learning process for face-to-face mode, including the course organization, instructor's enthusiasm, breadth of coverage, class size, type of course, student abilities, and grading policies. Some of these factors can be applied for measuring the effectiveness of a subject. The theory of constructivism indicates that a student's entire psychological, physiological and emotional energy is engaged in the learning process and that process is impacted by the environment.In addition to measuring student's academic knowledge, it is important to measure to what extent the goals of the curricula are achieved in order to determine the effectiveness of education(Baykul 1992).However, studies related to effectiveness(Rupsiene \& Bartuseviciene 2008) is refined as they generally cover complex activities. For this reason, difficulties can be overcomein the measurement of effectiveness by numerical index.

In a traditional context, in the field of chemistry, the level of reaching educational goals wasmeasured by the level of academic achievement of students, as is the case in other fields of science (Muijs 2006). For this reason, many different methods and approaches have been developed for the assessment and evaluation of academic achievement of students Okur \& Azar 2011).Therefore,it is important to identify a suitable approach to study the effectiveness of a subject in a study programme. The objective of this study is to develop a model to evaluate the effectiveness of a subject in a study programme

\section{Methodology}

The major components of questionnaire are the main features of a curriculum which are objectives, subject content, teaching learning methodology and evaluation. 


\section{International Journal of Science and Research (IJSR) \\ ISSN (Online): 2319-7064 \\ Index Copernicus Value (2015): 78.96 | Impact Factor (2015): 6.391}

Each major component includes statements which derived from literature and document analysis. Student handbook, curriculum and examination papers, Quality assurance report were used in the document analysis. Interviews of stake holder such as students and teachers were performedto corroborate the findings.

\section{Development of ELTA Tool}

Educational concepts, Learning environment and resource management, Teaching-learning process and Assessment (ELTA) were identified as main four factors relevant to the effectiveness of a subject in a curriculum. These factors are interrelated and depends on others.

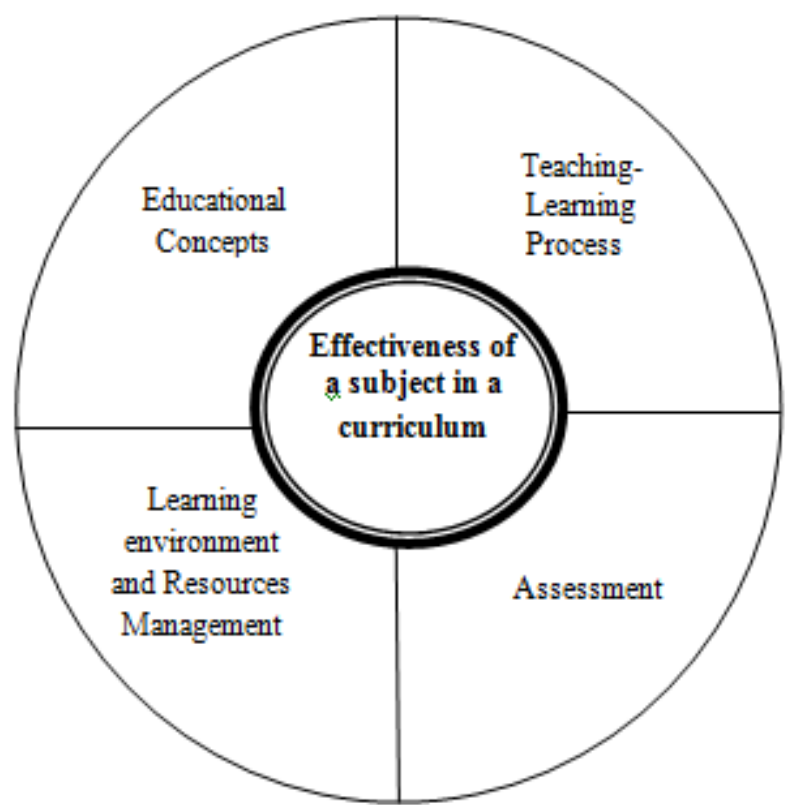

Figure 1: factors affecting the effectiveness of the subject

\section{Educational Concepts}

The application of educational concept is widely expected in both curricula and session planning, so that the expected outcome of a curriculum/lesson could be achieved with highest possible level of efficiency. Moreover, application of educational concept focus on instructional plans to satisfy the unique needs of the student, the educational settings and the curriculum to promote maximum learning. The current trend in educational concept focuses on student-centered learning (SCL), which shift in power from the expert teacher to the student learner (Barr \& Tagg 1995; Burnard 1999). It was reported thatthe students had increased participation and motivation in SCL(Hall \& Saunders 1997) and the approach was mostly respected by the students and boosted their confidence, which finally leads it to be effective approach (Lea et al. 2003). Therefore, the statements for educational concept based on the student centered learning approach were formulated as given in the table 1 .

Table 1: Perception on educational concepts
Students' perception on Educational concepts
1. Objectives are provided for all sections of the subject
2. Objectives are clear and achievable
3. Objectives are given for each session
4. Most of the objectives are covered by lectures
5. Each module/part is introduced stepwise from my basic knowledge of the subject.
6. Teachers informed us about the assessment methods at the beginning of the course
7. I learned and achieved the objectives by the learning session (Lecture or tutorial etc...)
8. I learned different topics by discussion with other students
9. I memorized most of the subject to study for examination
10. I learned principles and applied to new situations
Teachers' perception on Educational concepts
1. Current subject content is adequate to the programme
2. Objectives were prepared by the competent staff
3. Objectives were prepared in consultation with teachers of other related disciplines
4. Objectives are provided before starting the all session of the subject
5. Objectives are clearly worded with appropriate action verbs
6. Objectives are clearly explained to the students
7. Objectives are provided in cognitive, affective and psychomotor domains
8. Allocation of time for student learning is adequate
9. Objectives are modified based on feedback after implementation
10. Objectives are updated based on new knowledge

Volume 6 Issue 7, July 2017 www.ijsr.net 


\section{International Journal of Science and Research (IJSR) \\ ISSN (Online): 2319-7064}

Index Copernicus Value (2015): 78.96 | Impact Factor (2015): 6.391

\section{Learning Environment and Resource Management (LERM)}

An important responsibility of the institution is to provide a proper and conducive learning environment for the teacher and students. Use of educational technologies based on latest educational theories is essential to improve the learning environment and the quality of education (Jacobs 2010). The studies on learning environment highlights few aspects. One is the physical arrangement, which can affect the behavior of both students and teachers (Savage 1999) and a wellstructured classroom tends to improve students' academic and behavioral outcomes (MacAulay 1990; Walker \& Walker 1991; Walker \& Others 1995). The next is the use and organization of the resources, which helps to become independent and confident learners.Allocation of sufficient resources and its management is important to achieve the effectiveness of a subject. Library and media resources, computer facilities, support personnel should be adequate. Faculty, staff, and students should have access to appropriate buildings, classrooms, offices, study areas, furniture, equipment, library services, computers, media, and instructional materials. Since such resources are very important it should be sufficient and adequate (Walker \& Walker 1991). Another important aspect is classroom setting. Savage suggest that classrooms should be organized to accommodate a variety of activities throughout the day and to meet the teacher's instructional goals(Savage 1999). In addition, the classroom should be set up to set the stage for the teacher to address the academic, social, and emotional needs of students (MacAulay 1990). Considering the above research finding, the document analysis, and data from stakeholder, the statements for measuring LERM were formulated (Table 2).

Table 2: Perception on LERM

\begin{tabular}{l} 
Students' perception on LERM \\
1. Power point is better than Chalk and talk teaching \\
2. Updated materials are provided \\
3. Handouts are given for sessions \\
4. Seating arrangement is well designed for all of us to listen the presentation \\
5. Clearly heard the lecture/presentation without any other noise or disturbance \\
6. A variety of instructional strategies and activities are used to maintain interest \\
7. Used different methods to accommodate different learning approaches of students \\
8. The programme emphasized improvement rather than perfection \\
9. The session encouraged us to think and solve problems \\
10. I am always interested to attend the subject \\
11. Library staff are very helpful in locating information \\
12.I learned more this subject from reading in the library \\
13. I used internet to learn the subject \\
14. Intranet is provided for learning the subject \\
15.I used intranet to learn the subject \\
\hline Teachers' perception on LERM \\
1. The seating arrangement is well designed for all the students to listen my presentation \\
2. Students could clearly follow the session without any other noise or disturbance \\
3. A variety of instructional strategies are used to maintain interest in learning \\
4. Programme is designed to accommodate different learning approaches \\
5. The programme emphasized improvement rather than perfection \\
6. The session encouraged the students to think and solve problems \\
7. The environment is conducive for smooth inter personal interaction and respect for all \\
8. Internet is available to learn the subject \\
9. Intranet is provided for learning the subject \\
10. Library facilities are adequate to learn the subject y \\
11. Flow charts and illustrations are available for learning different modules. \\
12. Laboratory facilities are adequate for learning the subject \\
\end{tabular}

\section{Teaching-Learning process}

Teachers take the pivotal role in the teaching learning process. A professional teacher does not operate using a cookbook approach, blindly following a set of rules or procedures. This approach emphasizes not what one believes to be good teaching, but the emphasis is on characteristics and teacher behavior that are conducive to expected learning outcomes for students (Owoyemi \& Adesoji 2012).

According to Olaitain, teachers are the major operators of educational systems expected to effect and impart the needed knowledge to the students(Olaitain 2007). The effective class room management and discipline help to teach students responsibility and self-control, set the stage for optimal learning and reduce stress on the teacher(MacAulay 1990).

Students' expectations seems to learn in different kinds of class room settings (Taylor 1961). Student-centered learning as focusing on the students' learning is 'what students do to achieve this, rather than what the teacher does (Harden \& Crosby 2000). Results from the scientific literature (Kolb 1984) in the field of education have stated that experience and self-evaluation hold important roles in learning. The educational approaches should be in line with the experiential learning tradition and largely founded on peer review strategy for continuing education and quality improvement (Grol \& Lawrence 1995). 


\section{International Journal of Science and Research (IJSR) \\ ISSN (Online): 2319-7064 \\ Index Copernicus Value (2015): 78.96 | Impact Factor (2015): 6.391}

Problem-Based Learning (PBL) is contextualized and is learner centered learning to be effective in comparison with lecture based learning(Azer 2007). PBLhas become an important tool to enrich the learning of science and medicine (Parikh et al. 2001). PBL encourages the students to develop their own learning goals, thereby filling in the gaps in their knowledge or understanding (Boud \& Feletti 1999).Also Research findings show that students learn more effectively if the knowledge and skills they acquire are inserted and contextualized in relevant real-life, problem based situations (Glew \& VanderJagt 2001). Another important finding shows students preferred tutorials and revision classes than the lectures(Badyal et al. 2010). Ideally, teachers should possess a broad knowledge of their subjects, good classroom management and pedagogical skills and the motivation to help their students learn and succeed(Rao 1996).
Knowledge of the extent to which the expected leaning outcomes have been achieved will lead the student to be more effective and efficient learning (Jacobs 2010). It will provide for learners an insight into their performance that they might not otherwise have. Feedback is part of a twoway communication between a teacher or trainer and the learner. Feedback should be regarded as an essential teaching activity.

AsHattie \& Timperley (2007) reported, the most powerful tool that teachers can do to enhance achievement of their students is to provide them with feedback. Considering the above literature surveys, the document analysis, and data from stakeholder, the statements for measuring Teaching Learning process were formulated (Table 3 ).

Table 3: Perception on teaching learning process

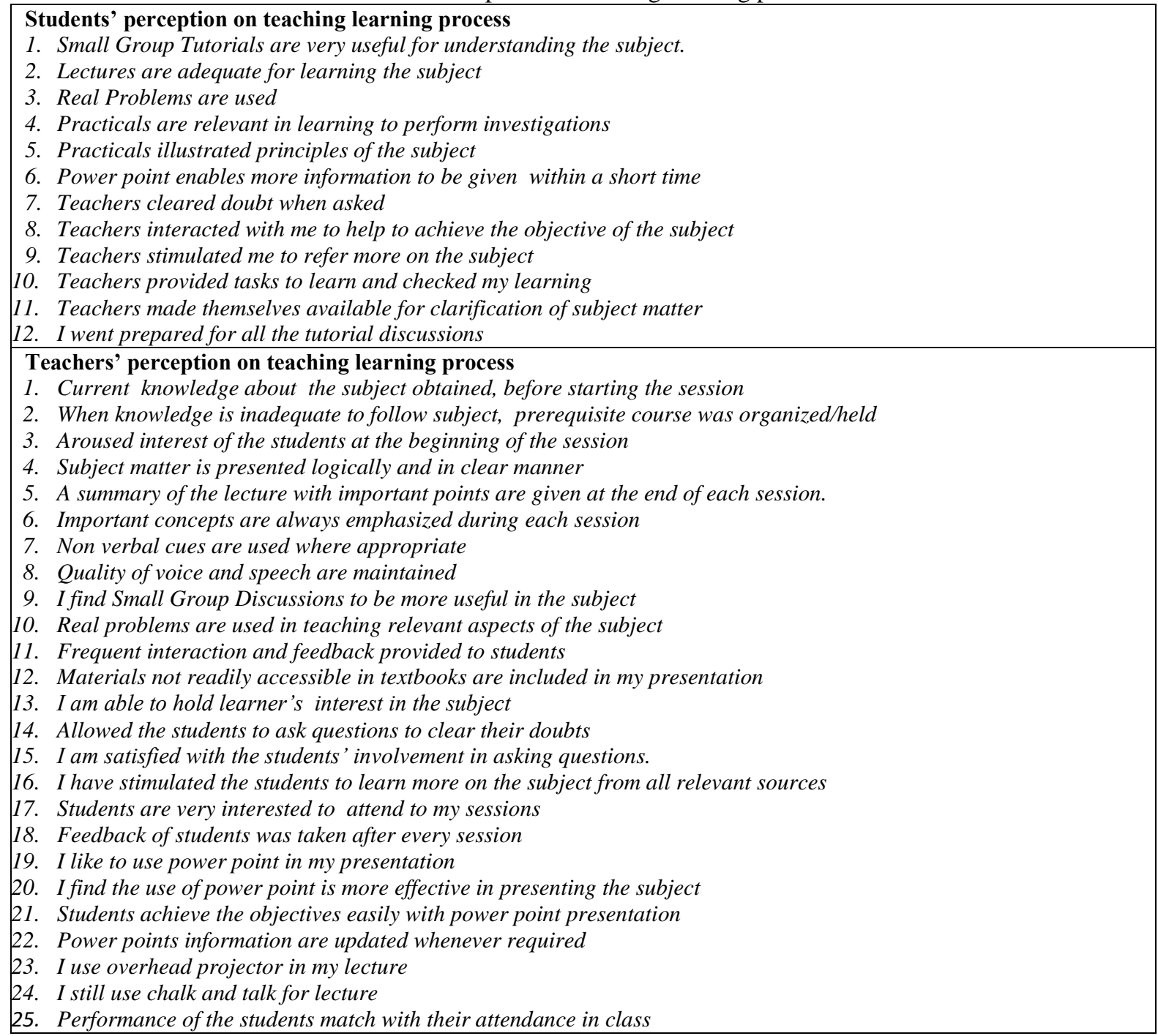

\section{Assessments}

Assessment is the process of obtaining a numerical description of the degree to which an individual possesses a particular characteristic (Gordon 2005). A definition of assessment in the Quality Assurance Agency (QAA) subject benchmark statement summarizes the approach to assessment in medical education: 'Assessment strategies and methods must ensure that the knowledge, understanding, skills and attitudes set out previously are sufficiently covered. Methods must be both valid and reliable. Appropriate procedures for standard setting should be employed.

Assessment of some qualities will require extended observations to be made(Sathaananthan \& Karunakaran 2009). While professional attitudes, for example, may be difficult to assess directly, the consequences of attitudes on

\section{Volume 6 Issue 7, July 2017}




\section{International Journal of Science and Research (IJSR) \\ ISSN (Online): 2319-7064}

Index Copernicus Value (2015): 78.96 | Impact Factor (2015): 6.391

behavior must be assessed usually by observation of that behavior over a period of time. Assessment needs to be thorough but should not be so heavy or so frequent as to interfere with the learning process (Medicine subject benchmark statement. 2010).

The Australian Medical Council medical school accreditation standards require assessments 'to be integrated across the curriculum to encourage students to develop an integrated approach to learning and a programmatic approach where multiple measures of student's knowledge, skills and abilities over time are aggregated to inform judgments about progress' (AMC 2009).
Fowell et al. (1999) noted that when devising suitable assessment systems, evaluating assessment is often omitted. And yet most educators involved in curriculum planning and development recognize the interplay between assessment and learning, and that to a large extent assessment drives learning. According to Gordon (2005), giving adequate assignments after each lesson was rated as one of the important factors for effectiveness in classroom. Considering the literature, the document analysis, and data from stakeholder, the statements for measuring Assessment were formulated (Table 4).

Table 4: Perception on Assessments

Students' perception on Assessments
1. All the questions given in the examination by the teachers are from the objectives provided
2. MCQ tested most of the subject content
3. Practical examination reflected objectives relating to skills
4. Structured essays are more useful than MCQ
5. Essay type questions are adequate to test the subject
6. Oral/ Viva voce tested my knowledge adequately
7. Continuous assessment (CA)was held with feedback after marking
8. Some percentage marks from CA is added with final score in the subject
Teachers perception on Assessments
1. Performance of the students match with their attendance in class.
2. All the questions in the assessment given to the students are relevant to test the achievement of the objectives
3. MCQ tested most of the subject contents
4. Practical examination used to test practical skills
5. Structured Essays are more useful than MCQ
6. Essay type Questions are adequate to test the objectives
7. Oral Viva is conducted in a reliable and valid manner

Steps for the application of ELTA model

1) Obtain the responses of questions in the form of five point scale as strongly agree-4, agree -3 , undecided-2, disagree- 1 , strongly disagree- 0 .

2) Calculate the total score of response in percentage.

3) Compare the response with inference table (Table 5), which is a modification of DundeeReady Education Environment Measure (DREEM) analysis (Roff 2005).

Table 5: Inference table based on response percentage

\begin{tabular}{|c|c|}
\hline The \% of response & Inference \\
\hline $00-49$ & Unsatisfactory(U) \\
\hline $50-74$ & Satisfactory $(\mathrm{S})$ \\
\hline $75-89$ & Good(G) \\
\hline $90-100$ & Excellent(E) \\
\hline
\end{tabular}

4) Calculate the average score for each of four factors for each respondent.

5) Express the degree of effectiveness of curriculum by calculate the correlationamong the above four factorsby correlation matrix analysis using average score.

6) Comparethe effectiveness of a subject in a curriculum among the faculties. This particular results can be used to indicate the difference in effectiveness among faculties and compare the effectiveness of a subject in a curriculum of all the faculties.

\section{Conclusion}

To evaluate the effectiveness of subject four parameters which areEducational concepts, Learning environment and resource management, Teaching-learning process, and Assessment (ELTA)were identified and the effectiveness of the subject can be measured by this ELTA model.

\section{References}

[1] AMC. 2009. Assessment and accreditation of medical schools: Standards and procedures.

[2] Azer SA. 2007. Medical education at the crossroads: Which way forward? Ann southi Med. 27:153-157.

[3] Badyal DK, Bala S, Kathuria P. 2010. Student evaluation of teaching and assessment methods in pharmacology. Indian J Pharmacol. 42:287-289.

[4] Barr RB, Tagg J. 1995. From teaching to learning: A new paradigm for undergraduate education. Change.:13-15.

[5] Baykul Y. 1992. Productivity and evaluation in education. Education. 113:307-311.

[6] Boud D, Feletti G. 1999. The Challenge of Problem Based Learning. London: Kogan Page.

[7] Burnard P. 1999. Carl Rogers and postmodernism: Challenged in nursing and health sciences. Nurs Heal Sci. 1:241.

[8] Fowell SL, Southgate LJ, Bligh JG. 1999. Evaluating assessment: the missing link? Med Educ. 33:276-281.

[9] Glew RH, VanderJagt DL. 2001. A Biochemistry of Human Disease course for undergraduate and graduate 


\section{International Journal of Science and Research (IJSR) \\ ISSN (Online): 2319-7064 \\ Index Copernicus Value (2015): 78.96 | Impact Factor (2015): 6.391}

students. Biochem Biol Educ. 29:188.

[10] Gordon HRD. 2005. Selected Factors of Teaching Effectiveness: Perceptions of Apprenticeship Trainers Effectiveness : Perceptions of. J Technol Stud.

[11] Grol R, Lawrence M. 1995. Quality Improvement by Peer Review. Oxford: Oxford University Press.

[12]Hall J, Saunders P. 1997. Adopting a student-centred approach to management of learning. In: Bell MB, Trott A, editors. Implement Flex Learn. Implementing Flexible Learning. London: Kogan Page.

[13] Harden RM, Crosby J. 2000. AMEE Guide No 20: The good teacher is more than a lecturer-the twelve roles of the teacher. Med Teach. 22:4.

[14] Hattie J, Timperley H. 2007. The power of feedback. Rev Educ Res. 77:81-112.

[15] Jacobs HH. 2010. Curriculum 21: Essential Education for a Changing World. Bill Sheskey. ASCD: Creating Learning Connections with Today?s Tech-Savvy Student.

[16] Kolb DA. 1984. Experiential Learning. Experience as the Source of Learning and Development. New Jersey: Prentice-Hall, Englewood Cliffs.

[17] Lea SJ, Stephenson D, Troy J. 2003. Higher Education Students? Attitudes to Student Centered Learning: Beyond ?educational bulimia? Stud High Educ. 28:3.

[18] MacAulay DJ. 1990. Classroom environment: A literature review. Educ Psychol. 10:239-253.

[19] Medicine subject benchmark statement. 2010. [place unknown]. Available from: http://www.qaa.ac.uk/academicinfrastructure/benchmar $\mathrm{k} /$ honours/

[20] Muijs D. 2006. Measuring teacher effectiveness: some methodological reflections. Educ Res Eval. 12:53-74.

[21] Okur M, Azar A. 2011. Primary teachers? opinions about alternative measurement and assessmenttechniques used in science and technology course. Kastamonu Educ J. 19:387-400.

[22] Olaitain SO. 2007. Review of problems of school guidance in Nigeria. J Educ Dev Areas. 1:10.

[23] Owoyemi TE, Adesoji FA. 2012. Isolation of Teaching Effectiveness Factors from Nigerian Senior Secondary School Chemistry Students? Point of View. Br J Arts Soc Sci. 9.

[24]Parikh A, Mcreelis K, Hodges B. 2001. Student feedback in problem based learning: a survey of 103 final year students across five Ontario medical schools. Science (80- ). 35:632-636.

[25] Rao Z. 1996. Reconciling communicative approaches to the teaching of English with traditional Chinese methods. Res English. 30:458-471.

[26]Roff S. 2005. The Dundee Ready Educational Environment Measure (DREEM) - a generic instrument for measuring students' perceptions of undergraduate health professions curricula. Med Teach [Internet]. 27:322-325. Available from: http://www.tandfonline.com/doi/full/10.1080/01421590 500151054

[27] Rupsiene L, Bartuseviciene I. 2008. Periodic diagnostic of students? academic achievements as a factor influencing study effectiveness. Tiltai. 2:27-44.

[28] Sathaananthan T, Karunakaran KE. 2009. Choice of assessment type for clinical teaching. In: Annu Res Sess. [place unknown]: Eastern University, Sri Lanka).
[29] Savage T V. 1999. Teaching self-control through management and discipline. Boston: Allyn and Bacon.

[30] Taylor R. 1961. The principles of curriculum development. Chicago, IL: University of Chicago Press.

[31] Walker HM, Others A. 1995. Antisocial Behavior in School: Strategies and Best Practices [Internet]. Pacific Grove, CA: Brooks/Cole Publishing Company. Available from: http://ezproxy.usherbrooke.ca/login?url=http://search.eb scohost.com/login.aspx ?direct $=$ true $\& \mathrm{db}=$ eric $\& A N=E D$ 389133\&site $=$ ehost-live

[32] Walker HM, Walker JE. 1991. Coping with noncompliance in the classroom: A positive approach for teachers. Austin, TX: Pro-Ed.

[33] Yilmaz K, Tasdan M. 2006. A qualitative research on the school administrators? thoughts about effectiveness in school administration, Ankara University. J Fac Educ Sci. 39:125-150. 